\title{
Physical activity and telomere length: Impact of aging and potential mechanisms of action
}

\author{
Nicole C. Arsenis ${ }^{1}$, Tongjian You ${ }^{2}$, Elisa F. Ogawa ${ }^{2}$, Grant M. Tinsley ${ }^{3}$ and Li Zuo ${ }^{4}$ \\ ${ }^{1}$ Department of Nursing, College of Nursing and Health Sciences, University of Massachusetts Boston, Boston, MA, USA \\ ${ }^{2}$ Department of Exercise and Health Sciences, College of Nursing and Health Sciences, University of Massachusetts Boston, \\ Boston, MA, USA \\ ${ }^{3}$ Department of Kinesiology \& Sport Management, Texas Tech University, Lubbock, TX, USA \\ ${ }^{4}$ Radiologic Sciences and Respiratory Therapy Division, School of Health and Rehabilitation Sciences, The Ohio State \\ University College of Medicine, Columbus, $\mathrm{OH}$, USA \\ Correspondence to: Tongjian You, email: tongjian.you@umb.edu \\ Li Zuo, email: zuo.4@osu.edu \\ Keywords: telomere length, leukocyte, muscle, physical activity, exercise \\ Received: October 21, $2016 \quad$ Accepted: March 16, $2017 \quad$ Published: March 30, 2017
}

Copyright: Arsenis et al. This is an open-access article distributed under the terms of the Creative Commons Attribution License 3.0 (CC BY 3.0), which permits unrestricted use, distribution, and reproduction in any medium, provided the original author and source are credited.

\section{ABSTRACT}

Telomeres protect the integrity of information-carrying DNA by serving as caps on the terminal portions of chromosomes. Telomere length decreases with aging, and this contributes to cell senescence. Recent evidence supports that telomere length of leukocytes and skeletal muscle cells may be positively associated with healthy living and inversely correlated with the risk of several age-related diseases, including cancer, cardiovascular disease, obesity, diabetes, chronic pain, and stress. In observational studies, higher levels of physical activity or exercise are related to longer telomere lengths in various populations, and athletes tend to have longer telomere lengths than non-athletes. This relationship is particularly evident in older individuals, suggesting a role of physical activity in combating the typical age-induced decrements in telomere length. To date, a small number of exercise interventions have been executed to examine the potential influence of chronic exercise on telomere length, but these studies have not fully established such relationship. Several potential mechanisms through which physical activity or exercise could affect telomere length are discussed, including changes in telomerase activity, oxidative stress, inflammation, and decreased skeletal muscle satellite cell content. Future research is needed to mechanistically examine the effects of various modalities of exercise on telomere length in middle-aged and older adults, as well as in specific clinical populations.

\section{INTRODUCTION}

Telomeres protect the integrity of informationcarrying DNA throughout cell cycle by serving as specialized DNA caps on chromosomes. During successive cellular divisions, telomeres prevent base pair loss of chromosomal DNA. Over time, telomere length decreases until the telomere becomes too short for the cell to divide, resulting in cellular senescence. This scenario is known as the end replication problem and describes the inability of DNA polymerase to replicate the terminal ends of the chromosomes (i.e. the telomeres) [1]. Telomerase, an enzyme with a catalytic unit termed protein reverse transcriptase, serves to combat the end replication problem through lengthening of telomeres [2].

It is suggested that telomere length may be a potential cellular marker for biological aging, as demonstrated by an inverse relationship between age and telomere length [3]. Although telomere length, and its attrition over time, is extremely variable among individuals, it is thought to be stable from childhood through young adulthood but begins to decrease in older adulthood [1]. Moreover, leukocyte telomere length is positively associated with number of years of healthy 
living, which may indicate that leukocyte telomere length is a biomarker for healthy aging [4].

Current evidence supports the idea that telomere length is associated with a number of chronic conditions including dyslipidemia [5], hypertension [6, 7], atherosclerosis $[8,9]$, stroke [10], coronary artery disease [11, 12], myocardial infarction [13], and poor cardiovascular disease prognosis $[10,14,15]$. Decreased leukocyte telomere length is also present in patients with colorectal $[16,17]$ and ovarian cancers [18]. It has been reported to be associated with high risks for gastric cancer [19], early onset of ovarian and breast cancers [20,21], as well as increased overall cancer incidence and mortality [22]. Furthermore, a number of studies indicate that telomere attrition is positively correlated with diabetes and diabetic complications [23-30]. For example, among type 2 diabetics, those experiencing complications such as diabetic nephropathy have shorter leukocyte telomere lengths than individuals without complications and those without diabetes [31].

It is well known that physical activity is associated with healthy aging and reduced risk for a number of chronic conditions [32], though the relationship between physical activity and telomere length remains unclear. Evidence supports an inverse relationship between telomere length and chronic pain $[33,34]$ and various psychological stresses [35-39]. Interestingly, in a study that measured stress levels in both sedentary and physically active individuals, perceived stress among sedentary individuals was negatively associated with telomere length, whereas among physically active individuals, perceived stress was not related to telomere length [40]. This suggests that physical activity may confer protection against stress-related telomere length shortening.

Based on the significance of telomere length in aging and the need to understand the potential association with physical activity, the purpose of this systematic review is to investigate whether physical activity and exercise influence telomere length and to discuss possible mechanisms of action.

\section{SEARCH STRATEGY}

A PubMed literature search was performed in accordance with the PRISMA statement [41]. The search focused on leukocyte and skeletal muscle telomere length in relation to exercise or physical activity. Search keywords included: "physical activity" OR "exercise" OR "lifestyle factors" OR "diet" OR "body weight" AND "telomere length" OR "telomerase", AND "leukocyte" OR "muscle". Inclusion criteria for each article were: an experimental or observational examination of telomere length in relation to physical activity or exercise at any age, a publication in the English language between 1998 and August 2016, and human participants.

\section{EFFECTS OF PHYSICAL ACTIVITY AND EXERCISE ON TELOMERE LENGTH}

\section{Observational studies}

Observational studies examining the potential relationship between physical activity/exercise and telomere length in skeletal muscle cells and leukocytes are summarized in Table 1 [42-44] and Table 2 [45-62], respectively. These studies were conducted in a broad set of individuals, including men and women, young to older adults, and healthy and chronically ill individuals.

Most of available research indicates that higher physical activity exhibits a positive relationship with longer leukocyte or skeletal muscle telomere length in comparison to a sedentary lifestyle. However, inconsistent results have been reported, and such discrepancies are potentially resulted from different exercise protocols (e.g., duration and intensity of physical activates), measured cell types, and self-reported activities (Table 1 and 2). One informative study reported that subjects in the $1^{\text {st }}$ quartile of exercise energy expenditure $(0-990 \mathrm{kcal} / \mathrm{wk})$ and $4^{\text {th }}$ quartile ( $\left.>3540 \mathrm{kcal} / \mathrm{wk}\right)$ had shorter peripheral blood mononuclear cell (PBMC) telomere length than those in the $2^{\text {nd }}$ quartile $(991-2340 \mathrm{kcal} / \mathrm{wk})$. There was no difference in PBMC telomere length between the $2^{\text {nd }}$ and $3^{\text {rd }}$ quartiles, suggesting that moderate levels of physical activity may be beneficial in protecting telomere shortening. Interestingly, telomerase activity in PBMC remains similar in all quartiles of physical activity [46]. This is in contrast with the findings of Werner et al. in which they observed that, compared to sedentary adults, active individuals participating in long-distance running showed elevated telomerase activity, increased telomerestabilizing proteins, down-regulated cell-cycle inhibitors, and decreased telomere erosion in the circulating leukocytes [47]. The conflicting results may be due to different sources of telomerase (PBMC vs. leukocytes) and a discrepancy in sample sizes between the two studies (69 vs. 104 subjects). More recent studies support that there is a clear dose-response relationship between movementbased behaviors and telomere length. Accordingly, greater vigorous physical activity is associated with a longer telomere length, as assessed in leukocytes and salivary DNA (Table 2).

Three independent studies evaluated the effect of moderate to vigorous aerobic exercise on skeletal muscle or leukocyte telomere length in young and older adults [44, $47,48]$. In elderly population, athletes had significantly longer skeletal muscle or leukocyte telomeres than nonathletes. However, athletic status appeared to show no marked association with telomere length in young adults. It is likely that telomere lengths in sedentary young adults have not yet experience attrition, but may eventually being 


\begin{tabular}{|c|c|c|c|}
\hline Study, Year & Participants & Physical Activity/Exercise Type & Influence on Telomere Length \\
\hline Kadi et al., 2008 & $\begin{array}{l}14 \text { healthy adults ( } 7 \text { non- } \\
\text { lifters, } 7 \text { power lifters) }\end{array}$ & Power lifting; $8 \pm 3$ years & $\begin{array}{l}\text { Longer skeletal muscle telomere } \\
\text { length in power lifters vs. non- } \\
\text { lifters }\end{array}$ \\
\hline Rae et al., 2010 & $\begin{array}{l}37 \text { adults }(19 \text { sedentary } \\
\text { subjects, } 18 \text { endurance } \\
\text { runners })\end{array}$ & $\begin{array}{l}\text { Endurance running; } 40 \mathrm{~km} / \text { week, } \\
\geq 7 \text { years }\end{array}$ & $\begin{array}{l}\text { Same skeletal muscle telomere } \\
\text { length in runners } v s \text {. sedentary } \\
\text { subjects. Shorter telomere length } \\
\text { in those with greater number of } \\
\text { years training } v s \text {. fewer number } \\
\text { of years training. } \\
\text { Shorter telomere length in those } \\
\text { with greater number of training } \\
\text { hours } v s \text {. fewer number of } \\
\text { training hours. }\end{array}$ \\
\hline Osthus et al., 2012 & $\begin{array}{l}20 \text { young and older men } \\
(10 \text { medium activity level, } \\
10 \text { endurance athletes })\end{array}$ & $\begin{array}{l}\text { Endurance exercise (long } \\
\text { distance skiing \& track running } \\
\text { competitions); Medium activity } \\
\text { (moderately physically active) }\end{array}$ & $\begin{array}{l}\text { Longer skeletal muscle telomere } \\
\text { length in older athletes } v s \text {. older } \\
\text { medium-activity individuals. } \\
\text { Same telomere length in young } \\
\text { athletes } v s \text {. young medium- } \\
\text { activity individuals. }\end{array}$ \\
\hline
\end{tabular}

affected by reduced telomerase activity if the sedentary lifestyle continues (Table 1 and 2).

Several researchers investigated additional factors that may correlate with telomere length. Studies showing differences between older athletes and non-athletes in their skeletal muscle or leukocyte telomere length also reported positive correlations between telomere length and aerobic fitness $\left(\mathrm{VO}_{2} \max \right)[46,47]$. In another study comparing marathon runners and sedentary adults, no difference in leukocyte telomere length was observed between the two groups, nor was there a correlation between telomere length and $\mathrm{VO}_{2}$ max across groups [54]. This lack of association may be due to study design considerations, such as the small sample size and a large variation in subjects' marathon running histories; alternatively, the high activity of marathon runners may also have detrimental effects on telomeres as mentioned previously. Among athletes, leukocyte telomere length has not been shown to be associated with body mass index (BMI) [53]. However, in healthy non-active subjects, there is an inverse correlation between leukocyte telomere length and BMI $[45,49]$.

The evidence indicates that individuals engaged in multiple healthy behaviors are more likely to maintain telomere length. Telomere length is likely altered by a variety of factors, and some may not yet be known, which could explain the mixed findings between physical activity/exercise and telomere length. For instance, a recent study examining a nationally representative US population showed that leukocyte telomere length moderately correlates with known cardiovascular risk factors such as blood glucose levels, thus serving as a potential predictor of cardiovascular diseases. Specifically, the percentage of body fat demonstrated a strong negative correlation with leukocyte telomere length regardless of age and health behaviors (e.g., physical activities) [63].
Psychological variables were also concurrently associated with telomere length as high anxiety and defensiveness are related to longer and shorter leukocyte telomeres, respectively [64]. Other factors, such as nutritional intake and its relation to oxidative stress and telomere length, are discussed in subsequent sections of this review. To date, many of the presently examined studies have been cross-sectional and involved small sample sizes, often comparing extremes of physical activity. However, even data from large observational studies examining a wide range of physical activity levels indicate that the association between physical activity and telomere length is not entirely clear. Weischer et al. examined relative leukocyte telomere length in 4,576 individuals on two occasions, with 10 years between each measurement [65]. The results of this analysis indicated that physical inactivity was associated with short telomere length, but not with the change in telomere length over the course of the 10-year observation period. These data, from a large pool of healthy participants, cast doubt on the influence of physical activity on telomere length [65].

\section{Interventional studies}

There are three reports of randomized controlled intervention study that investigated the effects of exercise on leukocyte telomere length, as summarized in Table 3 [66-68]. A study performed by Mason et al. showed that leukocyte telomere length is positively associated with baseline $\mathrm{VO}_{2}$ max and inversely associated with age, while unassociated with BMI and percent body fat [67]. However, no significant change in telomere length was found after exercise interventions, which is in accordance with the results of other two studies (Table 3). Despite the lack of an exercise effect on leukocyte telomere length, Sjögren et al. reported a strong negative correlation 
Table 2: Effects of physical activity/exercise on leukocyte telomere length: observational studies

\begin{tabular}{|c|c|c|c|}
\hline Study, Year & Participants & Physical Activity/Exercise Type & Influence on Telomere Length \\
\hline Cherkas et al., 2008 & 2401 white twin adults & $\begin{array}{l}\text { Self-reported physical activity ( } 4 \\
\text { groups based on physical activity } \\
\text { levels) }\end{array}$ & $\begin{array}{l}\text { Longer leukocyte telomere } \\
\text { length with increasing physical } \\
\text { activity level. }\end{array}$ \\
\hline Ludlow et al., 2008 & 69 adults & $\begin{array}{l}\text { Various aerobic exercise (divided } \\
\text { into quartiles based on exercise } \\
\text { energy } \\
\text { expenditure: 0-990, 991-2340, } \\
\text { 2341-3540, and 93541 kcal/wk) }\end{array}$ & $\begin{array}{l}\text { Longer leukocyte telomere } \\
\text { length in } 2^{\text {nd }} \text { quartile vs. } 1^{\text {st }} \text { and } \\
4^{\text {th }} \text { quartile. Same telomere } \\
\text { length in } 2^{\text {nd }} \text { quartile vs. } 3^{\text {rd }} \\
\text { quartile. }\end{array}$ \\
\hline Werner et al., 2009 & $\begin{array}{l}58 \text { young and } 46 \text { older } \\
\text { adults ( } 47 \text { healthy non- } \\
\text { athletes, } 57 \text { middle and } \\
\text { long-distance runners) }\end{array}$ & $\begin{array}{l}\text { Young athletes: } 73 \pm 4.8 \mathrm{~km} / \mathrm{wk} \\
\text { Older } \quad \text { athletes: } 80 \pm 7.5 \\
\mathrm{~km} / \mathrm{wk} ; \quad 35 \pm 2.7 \quad \text { years of } \\
\text { training experience }\end{array}$ & $\begin{array}{l}\text { Longer leukocyte telomere } \\
\text { length, higher telomere- } \\
\text { stabilizing proteins, lower } \\
\text { telomere erosion in athletes vs. } \\
\text { non-athletes. } \\
\text { Longer telomere length in older } \\
\text { athletes vs. older non-athletes. } \\
\text { Same telomere length in young } \\
\text { athletes vs. young non-athletes. }\end{array}$ \\
\hline LaRocca et al., 2010 & $\begin{array}{l}25 \text { healthy young and } 32 \\
\text { older adults ( } 30 \text { sedentary } \\
\text { subjects, } 27 \text { endurance } \\
\text { exercisers) }\end{array}$ & $\begin{array}{l}\text { Vigorous aerobic exercise } \geq 5 \\
\text { days/week, }>45 \mathrm{~min} / \text { day, } \geq 5 \text { years }\end{array}$ & $\begin{array}{l}\text { Same leukocyte telomere } \\
\text { length in older athletes vs. older } \\
\text { sedentary subjects } \\
\text { Same telomere length in young } \\
\text { athletes vs. young non-athletes. }\end{array}$ \\
\hline Song et al., 2010 & 80 healthy adults & Self-reported physical activity & $\begin{array}{l}\text { Self-reported physical activity } \\
\text { was not associated with } \\
\text { leukocyte telomere length, } \\
\text { but was associated with } \\
\text { accumulation of DNA damage. }\end{array}$ \\
\hline Krauss et al., 2011 & $\begin{array}{l}944 \text { adults with stable } \\
\text { coronary heart disease }\end{array}$ & Self-reported physical activity & $\begin{array}{l}\text { Self-reported physical activity } \\
\text { was associated with shorter } \\
\text { telomere length, but not after } \\
\text { multivariate adjustment }\end{array}$ \\
\hline Du et al., 2012 & 7,813 adult women & $\begin{array}{l}\text { Eight possible physical activities, } \\
\text { usual walking pace, and the } \\
\text { number of flights of stairs climbed } \\
\text { daily. }\end{array}$ & $\begin{array}{l}\text { Calisthenics/aerobics-associated } \\
\text { increase in leukocyte telomere } \\
\text { length }(0.10-\mathrm{SD}) \text { was observed } \\
\text { when comparing the most to the } \\
\text { least active women. }\end{array}$ \\
\hline Kim et al., 2012 & $\begin{array}{ll}44 & \text { healthy } \\
\text { postmenopausal } & \text { women } \\
(21 \quad \text { sedentary } & \text { subjects, } \\
23 \quad \text { habitual } & \text { exercise } \\
\text { participants }) & \\
\end{array}$ & $\begin{array}{l}\text { Aerobic and resistance exercise } \\
\text { for } 60+\text { minutes, }>3 \text { times per } \\
\text { week, for }>12 \text { months }\end{array}$ & $\begin{array}{l}\text { Longer leukocyte telomere } \\
\text { length in exercise participants vs. } \\
\text { sedentary subjects. }\end{array}$ \\
\hline Denham et al., 2013 & $\begin{array}{l}123 \text { males (56 healthy } \\
\text { non-marathon runners, } 67 \\
\text { ultra-marathon runners) }\end{array}$ & $\begin{array}{l}\text { Ultra-marathon running, average } \\
\text { distance } 40-100 \mathrm{~km} / \text { week, } \geq 2 \\
\text { years }\end{array}$ & $\begin{array}{l}\text { Longer leukocyte telomere } \\
\text { length in runners vs. non-runners. }\end{array}$ \\
\hline Mathur et al., 2013 & $\begin{array}{ll}32 & \text { middle-aged adults } \\
(15 \text { healthy } & \text { sedentary } \\
\text { subjects, } 17 & \text { marathon } \\
\text { runners }) & \\
\end{array}$ & $\begin{array}{l}\text { Marathon running, } 32 \pm 9 \text { miles/ } \\
\text { week, } 14 \pm 11 \text { years }\end{array}$ & $\begin{array}{l}\text { Same leukocyte telomere length } \\
\text { in runners vs. sedentary subjects. }\end{array}$ \\
\hline $\begin{array}{l}\text { Borghini et al. } \\
2015\end{array}$ & $\begin{array}{l}62 \text { adults ( } 20 \text { athletes, } 42 \\
\text { sedentary controls) }\end{array}$ & Endurance training & $\begin{array}{l}\text { Longer salivary telomere } \\
\text { length in endurance athletes vs. } \\
\text { sedentary controls. }\end{array}$ \\
\hline $\begin{array}{l}\text { Loprinzi et al } \\
2015\end{array}$ & 6503 adults & $\begin{array}{l}\text { Movement-based behaviors } \\
\text { (moderate-intensity and vigorous } \\
\text { intensity physical activity, } \\
\text { walking/cycling for transportation, } \\
\text { and muscle-strengthening } \\
\text { activities) }\end{array}$ & $\begin{array}{l}\text { A clear dose-response relation } \\
\text { was observed between } \\
\text { movement-based behaviors and } \\
\text { leukocyte telomere length. }\end{array}$ \\
\hline
\end{tabular}




\begin{tabular}{|c|c|c|c|}
\hline $\begin{array}{l}\text { Soares-Miranda et al } \\
2015\end{array}$ & 582 older adults & Self-reported physical activity & $\begin{array}{l}\text { Cross-sectional and longitudinal } \\
\text { analyses showed no significant } \\
\text { associations between physical } \\
\text { activity and leukocyte telomere } \\
\text { length }\end{array}$ \\
\hline $\begin{array}{l}\text { Saßenroth et al } \\
2015\end{array}$ & 815 older adults & Self-reported physical activity & $\begin{array}{l}\text { Physical activity was positively } \\
\text { associated with leukocyte } \\
\text { telomere length. Practicing a } \\
\text { sport for }>10 \text { years associated } \\
\text { with longer telomeres. } \\
\end{array}$ \\
\hline $\begin{array}{l}\text { Silva et al } \\
2016\end{array}$ & $\mid \begin{array}{llr}46 \quad \text { older } & \text { adults } & (15 \\
\text { intensively } & \text { trained, } & 16 \\
\text { moderately } & \text { trained, } & 15 \\
\text { untrained) } & & \end{array}$ & $\begin{array}{l}\text { Intensive training: training } \geq \\
5 \text { days/week ( }>50 \mathrm{~km} / \text { week); } \\
\text { moderate training: playing } \\
\text { volleyball, basketball, or running } \\
\text { less than } 6 \mathrm{~km}, 2-3 \text { days/week } \\
\end{array}$ & $\begin{array}{l}\text { Longer leukocyter telomere } \\
\text { length in trained vs. untrained } \\
\text { older adults. }\end{array}$ \\
\hline $\begin{array}{l}\text { Latifovic et al } \\
2016\end{array}$ & 477 healthy adults & Self-reported physical activity & $\begin{array}{l}\text { More vigorous physical activity } \\
\text { was associated with longer } \\
\text { leukocyte telomere length. }\end{array}$ \\
\hline Loprinzi et al 2016 & 6474 adults & Self-reported physical activity & $\begin{array}{l}\text { Meeting physical activity } \\
\text { guidelines for running, but not } \\
\text { other modes, was associated } \\
\text { with longer leukocyte telomere } \\
\text { length. }\end{array}$ \\
\hline Kanel et al 2016 & $\begin{array}{l}203 \text { African and } \\
\text { Caucasian school teachers }\end{array}$ & $\begin{array}{l}\text { Objectively measured physical } \\
\text { activity }\end{array}$ & $\begin{array}{l}\text { Habitual physical activity was } \\
\text { not associated with leukocyte } \\
\text { telomere length. }\end{array}$ \\
\hline
\end{tabular}

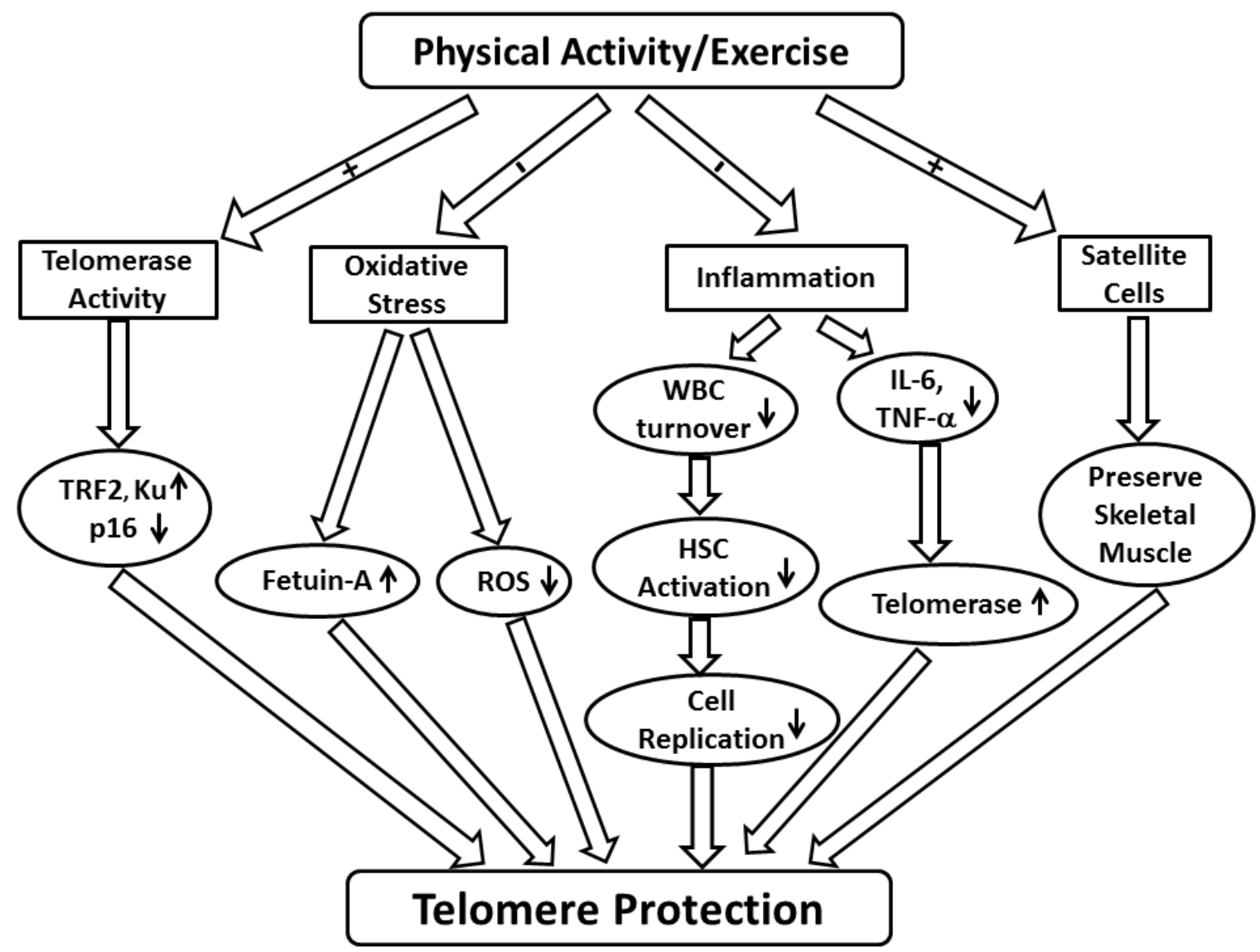

Figure 1: Schematic demonstrating the potential effects of physical activity and exercise on telomere length. Abbreviations: TRF2 (telomeric repeat-binding factor 2); ROS (reactive oxygen species); WBC (white blood cell); HSC (haematopoietic stem cell); IL (interleukin); TNF- $\alpha$ (tumor necrosis factor- $\alpha$ ). 


\begin{tabular}{|c|c|c|c|}
\hline Study, year & Participants & Intervention & Effects on telomere length \\
\hline Shin et al., 2008 & $\begin{array}{l}16 \text { obese, middle-aged } \\
\text { women } \\
(8 \text { control, } 8 \text { exercise })\end{array}$ & $\begin{array}{l}\text { No exercise control vs. aerobic } \\
\text { exercise training, } 6 \text { months }\end{array}$ & $\begin{array}{l}\text { Same leukocyte telomere length in } \\
\text { aerobic exercise vs. control. }\end{array}$ \\
\hline Mason et al., 2013 & $\begin{array}{l}439 \text { overweight, obese, } \\
\text { older adult ( } 87 \text { control, } \\
188 \text { dietary weight loss, } \\
117 \text { aerobic exercise, } \\
117 \text { diet \& exercise) }\end{array}$ & $\begin{array}{l}\text { No exercise control vs. aerobic } \\
\text { exercise training, } 5 \text { days per week, } \\
12 \text { months }\end{array}$ & $\begin{array}{l}\text { Same leukocyte telomere length } \\
\text { in aerobic exercise versus control. }\end{array}$ \\
\hline $\begin{array}{l}\text { Sjögren et al., } \\
2014\end{array}$ & $\begin{array}{l}49 \text { overweight and } \\
\text { abdominally obese } \\
\text { older adults }\end{array}$ & $\begin{array}{l}\text { Usual care with minimal } \\
\text { intervention control vs. moderate- } \\
\text { intensity aerobic/strength/flexibility/ } \\
\text { balance exercise intervention, most } \\
\text { days of the week for } 6 \text { months }\end{array}$ & $\begin{array}{l}\text { Same leukocyte telomere length in } \\
\text { exercise intervention vs. control. } \\
\text { Longer telomere length with } \\
\text { decreased sitting time in exercise } \\
\text { group. }\end{array}$ \\
\hline
\end{tabular}

between telomere length and sitting time in the exercise training group but not in the sedentary control group, suggesting a greater importance of reduced sitting time than increased exercise time in telomere maintenance [68].

In a small quasi-experiment study, investigators studied the effects of acute exercise on leukocyte recruitment and subsequent mean telomere length in young and old subjects [69]. After a single maximal bicycle exercise session, the mean telomere length in selected leukocyte subsets was shorter, likely due to recruitment of cells with a greater history of replication. These findings demonstrate that acute periods of exercise can lead to lower mean estimates of telomere length. Thus, the authors concluded that measures of leukocyte telomeres should not be obtained immediately following vigorous activity. Another acute exercise study observed that immediately after an episode of acute exercise, telomere length of CD8+ T-cells increased, whereas those of $\mathrm{CD} 4+$ and $\mathrm{CD} 3+$ cells did not. In addition, terminally differentiated CD8+ T-cells were released into the blood, which may indicate that more frequent exercise may allow naïve $T$ cells to populate and improve immune function [70]. It has also been reported that an acute exposure of ultra-distance endurance trail race reduced salivary telomere length in athletes, yet chronic endurance training provided protections against such shortening [55].

\section{MECHANISMS ASSOCIATED WITH TELOMERE SHORTENING}

Both chronic diseases and the aging process are known to be associated with decreased telomere length, but it may be possible to preserve telomere length with physical exercise. Although the existing literature does not provide adequate experimental evidence to fully establish the mechanistic relationship between physical exercise and telomere length, several potential mechanisms exist to explain how physical activity may affect telomere length: telomerase activity, oxidative stress, inflammation, and skeletal muscle satellite cell content (Figure 1).

\section{Telomerase activity}

While telomere length shows a progressive, agerelated shortening, telomerase demonstrated a biphasic pattern of expression. Iwama et al. reported that from age of 4 to 39 years, there is a progressive decrease in both telomere length and telomerase activity. However, in individuals aged 40 or over, where telomere length continued to progressively decrease, $65 \%$ of individuals had a stable but low telomerase activity, and the remaining $35 \%$ of individuals had no telomerase activity [71]. Physical activity could play a role in these processes. Werner et al. compared track and field athletes to sedentary adults, and found an up-regulation of telomeric repeat-binding factor 2 (TRF2), a protein that plays a role in protecting telomeres from shortening, in the athletes (both young and middle-aged) [47]. In young athletes, there was no change in the expression of $\mathrm{p} 16$, a negative regulator of cell cycle progression, nor $\mathrm{Ku}$ proteins, which are part of the DNA repair pathway. However, in middle-aged athletes, there was a down-regulation in p16 and up-regulation in $\mathrm{Ku}$ mRNA. These results suggest that paralleled with the regulation of TRF2, other transformation associated proteins such as $\mathrm{p} 16$ and $\mathrm{Ku}$ proteins may play a role in telomere protection in response to exercise for middle-aged individuals. No difference in leukocyte telomere length was observed between young athletes and young sedentary individuals. However, middle-aged sedentary adults had shorter telomeres compared to middle-aged athletes (Table 2). This agrees with the observed up-regulation of TRF2 in young and middle-aged athletes, as well as the observed upregulation of Ku proteins in middle-aged athletes.

\section{Oxidative Stress}

Excessive reactive oxygen species (ROS) production can cause oxidative stress in cells, tissues or organs [7274], leading to DNA damage and senescence or apoptosis [75]. Starr et al. determined that several oxidative- 
stress genes are linked with both telomere attrition and biological aging [76]. Moreover, decreased fetuin-A levels, a negative acute phase protein and mediator of redox homeostasis, have been associated with shortened leukocyte telomeres and increased risk for colorectal cancer and other diseases [16]. Correlations between shorter leukocyte telomeres and increased oxidative stress have also been reported in diabetics [24, 28]. Furthermore, telomere length was inversely associated with oxidative stress among the Framingham Heart Study Cohort in hypertensive individuals [77]. In fact, telomere length has been put forth as a potential marker of chronic oxidative stress because constant oxidative stress can compromise the repair mechanisms of telomeric DNA [78]. It has been proposed that chronic exercise may lower oxidative stress and therefore protect telomeres from shortening inflicted by excessive ROS [79]. Although oxidative stress can be detrimental to telomeres, proper levels of ROS may be protective. For example, a recent study reported that sperm telomere is lengthened by mild oxidative stress, although it is shortened by severe oxidative stress [80]. Therefore, it appears that the relationship between telomere length and oxidative stress is delicately balanced, whereby certain amount of ROS can aid in telomere maintenance, but this level must be lower than some thresholds to be less detrimental. Lifestyle factors other than exercise potentially play an important role in the modulation of telomere length through altering redox status. A recent research update by Freitas-Simoes and colleagues summarized the current body of evidence concerning dietary factors that impact telomere length, through oxidation and other mechanisms [81]. Diets that are higher in antioxidants from vegetables and whole grains appear to enhance telomere maintenance, and omega-3 fatty acids have emerged as a promising-but-understudied strategy to combat telomere attrition over time [82].

\section{Inflammation}

The attenuation of chronic inflammation provides another potential mechanism for the protective effects of exercise and physical activity on telomeres. For instance, chronic systemic inflammation elevates white blood cell (WBC) turnover, which increases telomere attrition rate [83]. With increased WBC turnover, the division of haematopoietic stem cells is activated, increasing cellular replication and subsequently leading to telomere shortening. Also, the pro-inflammatory cytokine tumor necrosis factor (TNF)- $\alpha$ may cause telomere shortening by downregulating telomerase [83]. Shortened leukocyte telomeres can be linked with elevated concentrations of both interleukin (IL)- 6 and TNF- $\alpha$. In addition, individuals with elevated concentrations of both IL-6 and TNF- $\alpha$ were more likely to have shortened leukocyte telomeres than those with high concentrations of only one of these molecules [84]. Of note, C-reactive protein (CRP) was not associated with telomere length in the same study, though others have observed a negative relationship between telomere length and CRP levels among patients with type2 diabetes [85].

Chronic obstructive pulmonary disease (COPD) patients have been reported to possess shorter mean leukocyte telomere length than healthy controls, which may be linked with chronic inflammation status in these patients. Specifically, IL-6 levels were inversely correlated with telomere length in COPD [86]. Zhang et al. recently described the complex interrelationship between aging, inflammation, and telomere length [87]. They draw attention to a number of proteins that may be involved in the induction of inflammation and telomere dysfunction, such as nuclear factor kappa B, Poly (ADPribose) polymerase 1 , Wnt, repressor-activator protein 1 , and telomerase reverse transcriptase. The manipulation of these proteins as a therapeutic strategy holds promise for combating inflammation and aging-related diseases. Physical activity is negatively related to levels of circulating inflammatory markers, and exercise training contributed to reduced levels of inflammatory markers in individuals with enhanced chronic inflammation $[88,89]$.

\section{Decreased satellite cells}

Satellite cells are skeletal muscle cell precursors which can regenerate muscle cells or additional satellite cells in response to muscle injury. After age 70, the number of satellite cells is reported to decrease [90]. This could contribute to the reductions of muscle mass seen in sedentary individuals, particularly during aging. It is estimated that approximately $40 \%$ of muscle tissue is lost by age 70 in sedentary individuals [91]. In older women, a positive correlation between the quantity of satellite cells and skeletal muscle telomere length has been reported [47], and satellite cells may serve as a mechanism through which physical activity can preserve skeletal muscle in older adults [90]. Physical activity acts to stimulate the satellite cell pool, which counteracts the decline of satellite cells that occurs with aging. Thus, satellite cell content represents another modifiable factor that can be altered in response to different physical activity levels and is therefore a potential player in the association between telomere length and physical activity. It has been suggested that the shortening of satellite cell telomeres leads to a diminished replication capacity in satellite cells [92]. This mechanism may be important in explaining agerelated loss of muscle mass.

\section{CLINICAL SIGNIFICANCE AND IMPLICATIONS}

Recent observational and experimental studies reveal a possible relationship between physical activity/exercise 
and telomere length, although this is not entirely clear from the present body of literature. Evidence has shown that physical activity decreases chronic inflammation and oxidative stress, especially in older, obese individuals, and may thus reduce telomere shortening observed with aging [67]. Therefore, exercise may potentially have a protective effect on telomere length, and may be especially beneficial for those at risk for or living with chronic conditions with high oxidative stress and inflammation.

In addition to physical activity, weight loss itself may reverse telomere attrition. Since age 50, women who were overweight or obese and later lost weight to be normal, or women who sustained a constant weight within $5 \%$, has shown greater leukocyte telomere length than those who gained weight after age 50 [93]. By maintaining a healthy weight and practicing healthy living through physical activity and dietary measures, individuals may be able to maintain an adequate telomere length and protect themselves from harmful effects of excessive inflammation and oxidative stress. For individuals with compromised musculoskeletal function, exercise may have therapeutic, preventive, and rehabilitative effects. Both resistance and aerobic trainings have been shown to increase the number of satellite cells, which may be important for regulating skeletal muscle telomere length [90]. Future studies should elucidate mechanisms of variations in telomere length, especially in adipose tissue, which may particularly provide more insight into the telomere biology in obese persons.

\section{CONCLUSIONS}

Telomere length has inverse associations with chronic conditions (including cardiovascular disease, obesity, and diabetes). Physical activity and exercise may be beneficial for telomere length maintenance in both healthy and chronically ill middle-aged and older adults. Telomere length is not only a marker of aging, but also relates to the ability to protect DNA from damage and the associated consequences. Individuals living with chronic conditions are more likely to be sedentary and experience functional limitations and disability. Physical activity and exercise may have both protective and restorative effects, and as such, show great potential to improve well-being and increase longevity. However, more interventional studies, especially those with longer-term exercise, are needed to confirm specific effects of various doses and intensities of exercise training on telomere length, particularly in middle-aged and older adults who are at increased risk for chronic diseases associated with inflammation and oxidative stress.

\section{ACKNOWLEDGMENTS}

We acknowledge the generous assistance from ChiaChen Chuang, Tingyang Zhou and Zewen Liu.

\section{CONFLICTS OF INTEREST}

The authors declare no conflicts of interest.

\section{REFERENCES}

1. Oeseburg H, de Boer RA, van Gilst WH, van der Harst P. Telomere biology in healthy aging and disease. Pflugers Arch. 2010; 459: 259-268.

2. Hohensinner PJ, Goronzy JJ, Weyand CM. Telomere dysfunction, autoimmunity and aging. Aging Dis. 2011; 2: 524-537.

3. Muezzinler A, Zaineddin AK, Brenner H. A systematic review of leukocyte telomere length and age in adults. Ageing Res Rev. 2013; 12: 509-519.

4. Njajou OT, Hsueh WC, Blackburn EH, Newman AB, Wu SH, Li R, Simonsick EM, Harris TM, Cummings SR, Cawthon RM. Association between telomere length, specific causes of death, and years of healthy life in health, aging, and body composition, a population-based cohort study. J Gerontol A Biol Sci Med Sci. 2009; 64: 860-864.

5. Dei Cas A, Spigoni V, Franzini L, Preti M, Ardigo D, Derlindati E, Metra M, Monti LD, Dell'Era P, Gnudi L, Zavaroni I. Lower endothelial progenitor cell number, family history of cardiovascular disease and reduced HDLcholesterol levels are associated with shorter leukocyte telomere length in healthy young adults. Nutr Metab Cardiovasc Dis. 2013; 23: 272-278.

6. Bhupatiraju C, Saini D, Patkar S, Deepak P, Das B, Padma T. Association of shorter telomere length with essential hypertension in Indian population. Am J Hum Biol. 2012; 24: 573-578.

7. Yang Z, Huang X, Jiang H, Zhang Y, Liu H, Qin C, Eisner GM, Jose PA, Rudolph L, Ju Z. Short telomeres and prognosis of hypertension in a chinese population. Hypertension. 2009; 53: 639-645.

8. Kark JD, Nassar H, Shaham D, Sinnreich R, Goldberger N, Aboudi V, Bogot NR, Kimura M, Aviv A. Leukocyte telomere length and coronary artery calcification in Palestinians. Atherosclerosis. 2013; 229: 363-368.

9. Willeit P, Willeit J, Brandstatter A, Ehrlenbach S, Mayr A, Gasperi A, Weger S, Oberhollenzer F, Reindl M, Kronenberg F, Kiechl S. Cellular aging reflected by leukocyte telomere length predicts advanced atherosclerosis and cardiovascular disease risk. Arterioscler Thromb Vasc Biol. 2010; 30: 1649-1656.

10. Zhang W, Chen Y, Wang Y, Liu P, Zhang M, Zhang C, $\mathrm{Hu}$ FB, Hui R. Short telomere length in blood leucocytes contributes to the presence of atherothrombotic stroke and haemorrhagic stroke and risk of post-stroke death. Clin Sci (Lond). 2013; 125: 27-36.

11. Fyhrquist F, Silventoinen K, Saijonmaa O, Kontula K, Devereux RB, de Faire U, Os I, Dahlof B. Telomere length and cardiovascular risk in hypertensive patients with left 
ventricular hypertrophy: the LIFE study. J Hum Hypertens. 2011; 25: 711-718.

12. Wang YY, Chen AF, Wang HZ, Xie LY, Sui KX, Zhang QY. Association of shorter mean telomere length with large artery stiffness in patients with coronary heart disease. Aging Male. 2011; 14: 27-32.

13. Zee RY, Michaud SE, Germer S, Ridker PM. Association of shorter mean telomere length with risk of incident myocardial infarction: a prospective, nested case-control approach. Clin Chim Acta. 2009; 403: 139-141.

14. Perez-Rivera JA, Pabon-Osuna P, Cieza-Borrella C, MartinHerrero F, Gonzalez-Porras JR, Gonzalez-Sarmiento R. Prognostic value of telomere length in acute coronary syndrome. Mech Ageing Dev. 2012; 133: 695-697.

15. Houben JM, Giltay EJ, Rius-Ottenheim N, Hageman GJ, Kromhout D. Telomere length and mortality in elderly men: the Zutphen Elderly Study. J Gerontol A Biol Sci Med Sci. 2011; 66: 38-44.

16. Maxwell F, McGlynn LM, Muir HC, Talwar D, Benzeval M, Robertson T, Roxburgh CS, McMillan DC, Horgan PG, Shiels PG. Telomere attrition and decreased fetuin-A levels indicate accelerated biological aging and are implicated in the pathogenesis of colorectal cancer. Clin Cancer Res. 2011; 17: 5573-5581.

17. Riegert-Johnson DL, Boardman LA, Crook JE, Thomas CS, Johnson RA, Roberts ME. Shorter peripheral blood telomeres are a potential biomarker for patients with advanced colorectal adenomas. Int J Biol Markers. 2012; 27: e375-380.

18. Mirabello L, Garcia-Closas M, Cawthon R, Lissowska J, Brinton LA, Peplonska B, Sherman ME, Savage SA. Leukocyte telomere length in a population-based casecontrol study of ovarian cancer: a pilot study. Cancer Causes Control. 2010; 21: 77-82.

19. Hou L, Savage SA, Blaser MJ, Perez-Perez G, Hoxha M, Dioni L, Pegoraro V, Dong LM, Zatonski W, Lissowska J, Chow WH, Baccarelli A. Telomere length in peripheral leukocyte DNA and gastric cancer risk. Cancer Epidemiol Biomarkers Prev. 2009; 18: 3103-3109.

20. Martinez-Delgado B, Yanowsky K, Inglada-Perez L, de la Hoya M, Caldes T, Vega A, Blanco A, Martin T, GonzalezSarmiento R, Blasco M, Robledo M, Urioste M, Song H, et al. Shorter telomere length is associated with increased ovarian cancer risk in both familial and sporadic cases. $\mathrm{J}$ Med Genet. 2012; 49: 341-344.

21. Martinez-Delgado B, Yanowsky K, Inglada-Perez L, Domingo S, Urioste M, Osorio A, Benitez J. Genetic anticipation is associated with telomere shortening in hereditary breast cancer. PLoS Genet. 2011; 7: e1002182.

22. Willeit P, Willeit J, Mayr A, Weger S, Oberhollenzer F, Brandstatter A, Kronenberg F, Kiechl S. Telomere length and risk of incident cancer and cancer mortality. JAMA. 2010; 304: 69-75.

23. Adaikalakoteswari A, Balasubramanyam M, Ravikumar R,
Deepa R, Mohan V. Association of telomere shortening with impaired glucose tolerance and diabetic macroangiopathy. Atherosclerosis. 2007; 195: 83-89.

24. Ma D, Zhu W, Hu S, Yu X, Yang Y. Association between oxidative stress and telomere length in Type 1 and Type 2 diabetic patients. J Endocrinol Invest. 2013; 36: 1032-1037.

25. Shen Q, Zhao X, Yu L, Zhang Z, Zhou D, Kan M, Zhang D, Cao L, Xing Q, Yang Y, Xu H, He L, Liu Y. Association of leukocyte telomere length with type 2 diabetes in mainland Chinese populations. J Clin Endocrinol Metab. 2012; 97: 1371-1374.

26. Zee RY, Castonguay AJ, Barton NS, Germer S, Martin M. Mean leukocyte telomere length shortening and type 2 diabetes mellitus: a case-control study. Transl Res. 2010; 155: 166-169.

27. Salpea KD, Talmud PJ, Cooper JA, Maubaret CG, Stephens JW, Abelak K, Humphries SE. Association of telomere length with type 2 diabetes, oxidative stress and UCP2 gene variation. Atherosclerosis. 2010; 209: 42-50.

28. Sampson MJ, Winterbone MS, Hughes JC, Dozio N, Hughes DA. Monocyte telomere shortening and oxidative DNA damage in type 2 diabetes. Diabetes Care. 2006; 29 : 283-289.

29. Monickaraj F, Aravind S, Gokulakrishnan K, Sathishkumar C, Prabu P, Prabu D, Mohan V, Balasubramanyam M. Accelerated aging as evidenced by increased telomere shortening and mitochondrial DNA depletion in patients with type 2 diabetes. Mol Cell Biochem. 2012; 365: 343350 .

30. Harte AL, da Silva NF, Miller MA, Cappuccio FP, Kelly A, O'Hare JP, Barnett AH, Al-Daghri NM, Al-Attas O, Alokail M, Sabico S, Tripathi G, Bellary S, et al. Telomere length attrition, a marker of biological senescence, is inversely correlated with triglycerides and cholesterol in South Asian males with type 2 diabetes mellitus. Exp Diabetes Res. 2012; 2012: 895185 .

31. Testa R, Olivieri F, Sirolla C, Spazzafumo L, Rippo MR, Marra M, Bonfigli AR, Ceriello A, Antonicelli R, Franceschi C, Castellucci C, Testa I, Procopio AD. Leukocyte telomere length is associated with complications of type 2 diabetes mellitus. Diabet Med. 2011; 28: 13881394.

32. Bauman AE, Smith BJ. Healthy ageing: what role can physical activity play? Med J Aust. 2000; 173: 88-90.

33. Hassett AL, Epel E, Clauw DJ, Harris RE, Harte SE, Kairys A, Buyske S, Williams DA. Pain is associated with short leukocyte telomere length in women with fibromyalgia. J Pain. 2012; 13: 959-969.

34. Sibille KT, Langaee T, Burkley B, Gong Y, Glover TL, King C, Riley JL 3rd, Leeuwenburgh C, Staud R, Bradley LA, Fillingim RB. Chronic pain, perceived stress, and cellular aging: an exploratory study. Mol Pain. 2012; 8: 12.

35. van Ockenburg SL, de Jonge P, van der Harst P, Ormel J, Rosmalen JG. Does neuroticism make you old? Prospective 
associations between neuroticism and leukocyte telomere length. Psychol Med. 2014; 44: 723-729.

36. Yen YC, Lung FW. Older adults with higher income or marriage have longer telomeres. Age Ageing. 2013; 42: 234-239.

37. Shiels PG, McGlynn LM, MacIntyre A, Johnson PC, Batty GD, Burns H, Cavanagh J, Deans KA, Ford I, McConnachie A, McGinty A, McLean JS, Millar K, et al. Accelerated telomere attrition is associated with relative household income, diet and inflammation in the pSoBid cohort. PLoS One. 2011; 6: e22521.

38. Parks CG, DeRoo LA, Miller DB, McCanlies EC, Cawthon RM, Sandler DP. Employment and work schedule are related to telomere length in women. Occup Environ Med. 2011; 68: 582-589.

39. Fujishiro K, Diez-Roux AV, Landsbergis PA, Jenny NS, Seeman T. Current employment status, occupational category, occupational hazard exposure and job stress in relation to telomere length: the Multiethnic Study of Atherosclerosis (MESA). Occup Environ Med. 2013; 70: 552-560.

40. Puterman E, Lin J, Blackburn E, O'Donovan A, Adler $\mathrm{N}$, Epel E. The power of exercise: buffering the effect of chronic stress on telomere length. PLoS One. 2010; 5: e10837.

41. Moher D, Liberati A, Tetzlaff J, Altman DG, Group P. Preferred reporting items for systematic reviews and metaanalyses: the PRISMA statement. Ann Intern Med. 2009; 151: 264-269, W264.

42. Kadi F, Ponsot E, Piehl-Aulin K, Mackey A, Kjaer M, Oskarsson E, Holm L. The effects of regular strength training on telomere length in human skeletal muscle. Med Sci Sports Exerc. 2008; 40: 82-87.

43. Rae DE, Vignaud A, Butler-Browne GS, Thornell LE, Sinclair-Smith C, Derman EW, Lambert MI, Collins M. Skeletal muscle telomere length in healthy, experienced, endurance runners. Eur J Appl Physiol. 2010; 109: 323-330.

44. Osthus IB, Sgura A, Berardinelli F, Alsnes IV, Bronstad E, Rehn T, Stobakk PK, Hatle H, Wisloff U, Nauman J. Telomere length and long-term endurance exercise: does exercise training affect biological age? A pilot study. PLoS One. 2012; 7: e52769.

45. Cherkas LF, Hunkin JL, Kato BS, Richards JB, Gardner JP, Surdulescu GL, Kimura M, Lu X, Spector TD, Aviv A. The association between physical activity in leisure time and leukocyte telomere length. Arch Intern Med. 2008; 168: 154-158.

46. Ludlow AT, Zimmerman JB, Witkowski S, Hearn JW, Hatfield BD, Roth SM. Relationship between physical activity level, telomere length, and telomerase activity. Med Sci Sports Exerc. 2008; 40: 1764-1771.

47. Werner C, Furster T, Widmann T, Poss J, Roggia C, Hanhoun M, Scharhag J, Buchner N, Meyer T, Kindermann W, Haendeler J, Bohm M, Laufs U. Physical exercise prevents cellular senescence in circulating leukocytes and in the vessel wall. Circulation. 2009; 120: 2438-2447.

48. LaRocca TJ, Seals DR, Pierce GL. Leukocyte telomere length is preserved with aging in endurance exercise-trained adults and related to maximal aerobic capacity. Mech Ageing Dev. 2010; 131: 165-167.

49. Song Z, von Figura G, Liu Y, Kraus JM, Torrice C, Dillon P, Rudolph-Watabe M, Ju Z, Kestler HA, Sanoff H, Lenhard Rudolph K. Lifestyle impacts on the agingassociated expression of biomarkers of DNA damage and telomere dysfunction in human blood. Aging Cell. 2010; 9: 607-615.

50. Krauss J, Farzaneh-Far R, Puterman E, Na B, Lin J, Epel E, Blackburn E, Whooley MA. Physical fitness and telomere length in patients with coronary heart disease: findings from the Heart and Soul Study. PLoS One. 2011; 6: e26983.

51. Du M, Prescott J, Kraft P, Han J, Giovannucci E, Hankinson SE, De Vivo I. Physical activity, sedentary behavior, and leukocyte telomere length in women. Am J Epidemiol. 2012; 175: 414-422.

52. Kim JH, Ko JH, Lee DC, Lim I, Bang H. Habitual physical exercise has beneficial effects on telomere length in postmenopausal women. Menopause. 2012; 19: 1109-1115.

53. Denham J, Nelson CP, O'Brien BJ, Nankervis SA, Denniff M, Harvey JT, Marques FZ, Codd V, ZukowskaSzczechowska E, Samani NJ, Tomaszewski M, Charchar FJ. Longer leukocyte telomeres are associated with ultraendurance exercise independent of cardiovascular risk factors. PLoS One. 2013; 8: e69377.

54. Mathur S, Ardestani A, Parker B, Cappizzi J, Polk D, Thompson PD. Telomere length and cardiorespiratory fitness in marathon runners. J Investig Med. 2013; 61: 613615.

55. Borghini A, Giardini G, Tonacci A, Mastorci F, Mercuri A, Mrakic-Sposta S, Moretti S, Andreassi MG, Pratali L. Chronic and acute effects of endurance training on telomere length. Mutagenesis. 2015; 30: 711-716.

56. Loprinzi PD, Loenneke JP, Blackburn EH. MovementBased Behaviors and Leukocyte Telomere Length among US Adults. Med Sci Sports Exerc. 2015; 47: 2347-2352.

57. Soares-Miranda L, Imamura F, Siscovick D, Jenny NS, Fitzpatrick AL, Mozaffarian D. Physical Activity, Physical Fitness, and Leukocyte Telomere Length: The Cardiovascular Health Study. Med Sci Sports Exerc. 2015; 47: 2525-2534.

58. Sassenroth D, Meyer A, Salewsky B, Kroh M, Norman K, Steinhagen-Thiessen E, Demuth I. Sports and Exercise at Different Ages and Leukocyte Telomere Length in Later Life--Data from the Berlin Aging Study II (BASE-II). PLoS One. 2015; 10: e0142131.

59. Silva LC, de Araujo AL, Fernandes JR, Matias Mde S, Silva PR, Duarte AJ, Garcez Leme LE, Benard G. Moderate and intense exercise lifestyles attenuate the effects of aging on telomere length and the survival and composition of $\mathrm{T}$ cell 
subpopulations. Age (Dordr). 2016; 38: 24.

60. Latifovic L, Peacock SD, Massey TE, King WD. The Influence of Alcohol Consumption, Cigarette Smoking, and Physical Activity on Leukocyte Telomere Length. Cancer Epidemiol Biomarkers Prev. 2016; 25: 374-380.

61. Loprinzi PD, Sng E. Mode-specific physical activity and leukocyte telomere length among U.S. adults: Implications of running on cellular aging. Prev Med. 2016; 85: 17-19.

62. VON Kanel R, Bruwer EJ, DE Ridder H, Malan L. Association between objectively measured physical activity, chronic stress and leukocyte telomere length. J Sports Med Phys Fitness. 2016 Apr 13. [Epub ahead of print].

63. Rehkopf DH, Needham BL, Lin J, Blackburn EH, Zota AR, Wojcicki JM, Epel ES. Leukocyte Telomere Length in Relation to 17 Biomarkers of Cardiovascular Disease Risk: A Cross-Sectional Study of US Adults. PLoS Med. 2016; 13: e1002188.

64. Starnino L, Busque L, Tardif JC, D'Antono B. Psychological Profiles in the Prediction of Leukocyte Telomere Length in Healthy Individuals. PLoS One. 2016; 11: e0165482.

65. Weischer M, Bojesen SE, Nordestgaard BG. Telomere shortening unrelated to smoking, body weight, physical activity, and alcohol intake: 4,576 general population individuals with repeat measurements 10 years apart. PLoS Genet. 2014; 10: e1004191.

66. Shin YA, Lee JH, Song W, Jun TW. Exercise training improves the antioxidant enzyme activity with no changes of telomere length. Mech Ageing Dev. 2008; 129: 254-260.

67. Mason C, Risques RA, Xiao L, Duggan CR, Imayama I, Campbell KL, Kong A, Foster-Schubert KE, Wang CY, Alfano CM, Blackburn GL, Rabinovitch PS, McTiernan A. Independent and combined effects of dietary weight loss and exercise on leukocyte telomere length in postmenopausal women. Obesity (Silver Spring). 2013; 21: E549-554.

68. Sjögren P, Fisher R, Kallings L, Svenson U, Roos G, Hellenius ML. Stand up for health--avoiding sedentary behaviour might lengthen your telomeres: secondary outcomes from a physical activity RCT in older people. Br J Sports Med. 2014; 48: 1407-1409.

69. Bruunsgaard H, Jensen MS, Schjerling P, HalkjaerKristensen J, Ogawa K, Skinhoj P, Pedersen BK. Exercise induces recruitment of lymphocytes with an activated phenotype and short telomeres in young and elderly humans. Life Sci. 1999; 65: 2623-2633.

70. Simpson RJ, Cosgrove C, Chee MM, McFarlin BK, Bartlett DB, Spielmann G, O'Connor DP, Pircher H, Shiels PG. Senescent phenotypes and telomere lengths of peripheral blood T-cells mobilized by acute exercise in humans. Exerc Immunol Rev. 2010; 16: 40-55.

71. Iwama H, Ohyashiki K, Ohyashiki JH, Hayashi S, Yahata N, Ando K, Toyama K, Hoshika A, Takasaki M, Mori M, Shay JW. Telomeric length and telomerase activity vary with age in peripheral blood cells obtained from normal individuals. Hum Genet. 1998; 102: 397-402.

72. Zuo L, Shiah A, Roberts WJ, Chien MT, Wagner PD, Hogan MC. Low Po(2) conditions induce reactive oxygen species formation during contractions in single skeletal muscle fibers. Am J Physiol Regul Integr Comp Physiol. 2013; 304: R1009-1016.

73. Zuo L, Roberts WJ, Tolomello RC, Goins AT. Ischemic and hypoxic preconditioning protect cardiac muscles via intracellular ROS signaling. Front Biol. 2013; 8: 305-311.

74. Zuo L, Best TM, Roberts WJ, Diaz PT, Wagner PD. Characterization of reactive oxygen species in diaphragm. Acta Physiol (Oxf). 2015; 213: 700-710.

75. Barouki R. Ageing free radicals and cellular stress. [Article in French]. Med Sci (Paris). 2006; 22: 266-272.

76. Starr JM, Shiels PG, Harris SE, Pattie A, Pearce MS, Relton CL, Deary IJ. Oxidative stress, telomere length and biomarkers of physical aging in a cohort aged 79 years from the 1932 Scottish Mental Survey. Mech Ageing Dev. 2008; 129: 745-751.

77. Demissie S, Levy D, Benjamin EJ, Cupples LA, Gardner JP, Herbert A, Kimura M, Larson MG, Meigs JB, Keaney JF, Aviv A. Insulin resistance, oxidative stress, hypertension, and leukocyte telomere length in men from the Framingham Heart Study. Aging Cell. 2006; 5: 325-330.

78. Houben JM, Moonen HJ, van Schooten FJ, Hageman GJ. Telomere length assessment: biomarker of chronic oxidative stress? Free Radic Biol Med. 2008; 44: 235-246.

79. Radak Z, Chung HY, Koltai E, Taylor AW, Goto S. Exercise, oxidative stress and hormesis. Ageing Res Rev. 2008; 7 : 34-42.

80. Mishra S, Kumar R, Malhotra N, Singh N, Dada R. Mild oxidative stress is beneficial for sperm telomere length maintenance. World J Methodol. 2016; 6: 163-170.

81. Freitas-Simoes TM, Ros E, Sala-Vila A. Nutrients, foods, dietary patterns and telomere length: Update of epidemiological studies and randomized trials. Metabolism. 2016; 65: 406-415.

82. Shammas MA. Telomeres, lifestyle, cancer, and aging. Curr Opin Clin Nutr Metab Care. 2011; 14: 28-34.

83. Khan S, Chuturgoon AA, Naidoo DP. Telomeres and atherosclerosis. Cardiovasc J Afr. 2012; 23: 563-571.

84. O'Donovan A, Pantell MS, Puterman E, Dhabhar FS, Blackburn EH, Yaffe K, Cawthon RM, Opresko PL, Hsueh WC, Satterfield S, Newman AB, Ayonayon HN, Rubin SM, et al. Cumulative inflammatory load is associated with short leukocyte telomere length in the Health, Aging and Body Composition Study. PLoS One. 2011; 6: e19687.

85. Al-Attas OS, Al-Daghri NM, Alokail MS, Alfadda A, Bamakhramah A, Sabico S, Pritlove D, Harte A, Tripathi G, McTernan PG, Kumar S, Chrousos G. Adiposity and insulin resistance correlate with telomere length in middleaged Arabs: the influence of circulating adiponectin. Eur J Endocrinol. 2010; 163: 601-607.

86. Savale L, Chaouat A, Bastuji-Garin S, Marcos E, Boyer L, 
Maitre B, Sarni M, Housset B, Weitzenblum E, Matrat M, Le Corvoisier P, Rideau D, Boczkowski J, et al. Shortened telomeres in circulating leukocytes of patients with chronic obstructive pulmonary disease. Am J Respir Crit Care Med. 2009; 179: 566-571.

87. Zhang J, Rane G, Dai X, Shanmugam MK, Arfuso F, Samy RP, Lai MK, Kappei D, Kumar AP, Sethi G. Ageing and the telomere connection: An intimate relationship with inflammation. Ageing Res Rev. 2016; 25: 55-69.

88. You T, Arsenis NC, Disanzo BL, Lamonte MJ. Effects of exercise training on chronic inflammation in obesity : current evidence and potential mechanisms. Sports Med. 2013; 43: 243-256.

89. Nimmo MA, Leggate M, Viana JL, King JA. The effect of physical activity on mediators of inflammation. Diabetes Obes Metab. 2013; 15 Suppl 3: 51-60.
90. Kadi F, Ponsot E. The biology of satellite cells and telomeres in human skeletal muscle: effects of aging and physical activity. Scand J Med Sci Sports. 2010; 20: 39-48.

91. Sharples AP, Hughes DC, Deane CS, Saini A, Selman C, Stewart CE. Longevity and skeletal muscle mass: the role of IGF signalling, the sirtuins, dietary restriction and protein intake. Aging Cell. 2015; 14: 511-523.

92. Meyer A, Salewsky B, Spira D, Steinhagen-Thiessen E, Norman K, Demuth I. Leukocyte telomere length is related to appendicular lean mass: cross-sectional data from the Berlin Aging Study II (BASE-II). Am J Clin Nutr. 2016; 103: 178-183.

93. Cui Y, Gao YT, Cai Q, Qu S, Cai H, Li HL, Wu J, Ji BT, Yang G, Chow WH, Shu XO, Zheng W. Associations of leukocyte telomere length with body anthropometric indices and weight change in Chinese women. Obesity (Silver Spring). 2013; 21: 2582-2588. 